\title{
Orfan's Robot
}

David Halliday

Orfan had been labouring in his garage in Kabul for the last eighteen years. He had spent his boyhood building a robot out of old bike parts, motorbike engines and computer processors, and now, as a twenty-six year old man, his project was finally coming to fruition. A lawn-mower motor drove the gears, which cranked the bike-chain tendons in its torso, operating stiff arms and legs on greased ball joints. Orfan's robot was named Cyclot. It had started as a hobby, but when the Taliban came into power in 1996, he knew that if a robot of the Hazara people was discovered, it would be taken and destroyed. With a mass exodus of the Hazara, he moved his base of operations underground (both figuratively and literally) into an empty ex-Soviet bunker that smelled of motor oil, urine and stale dahl, before crossing the border and resuming construction in the city of Quetta, the fruit basket of Pakistan. When the Taliban was 
ousted by the Americans, he had returned to the dusty shadows of that same garage, in a land bearing marks of incidental violation and neglect.

Orfan yanked Cyclot's ignition cable like a lawnmower, and the robot spluttered into operation. He grabbed the remote control, fiddled with the thumb knobs and Cyclot stood up and his shuttered eye-lights glowed yellow.

'Come on, Cyclot. Time to go.' Orphan led Cyclot out of the garage, the robot teetering on uncertain feet. While building the machine, Orfan had whiled away the hours dreaming great dreams. His fantasies had carried him away! With every new bolt, every new wire, he imagined himself with overnight fame, like the guy in Slumdog Millionaire! It was his destiny. He would take part in the contemporary, media-driven, infotainment universe and have a hefty slice of the ephemeral fame granted to all in America. Orfan didn't know about Andy Warhol, but rumours of the coveted fifteen minutes of fame available to all had reached his ears many times. Fame! Everyone had it there! He wondered why all countries hadn't arrived at a democratic form of government where everyone was assured fame even earlier. Orphan's robot was the key to his own slice of fame. He would make appearances on television shows like Late Night With Conan O'Brien, The Jay Leno Show, or The Oprah Winfrey Show. Definitely Oprah. She would make him cry and he would make her cry with his tale of hardship; building robots and fleeing the Taliban in Afghanistan, where so many of America's sons and daughters were faithfully serving the cause of justice. They would cry and hug and reinforce the loving structure of the human tribe. Oprah's lips would glisten and she would smell clean like lavender 
and rich like roast lamb with rosemary. They would love each other and wonder why it took so long to arrive at that moment in time.

Orfan dreamed of Letterman, David Letterman. It was a name he almost whispered. Dare he dream so big? Letterman would try to make light of his troubles. He would laugh at Cyclot, the robot who would perform: spinning plates on sticks, or defusing land mines or spinning land mines while defusing them.

Orfan also dreamed of being on Ellen. She would be sympathetic, but would make fun of him too, turning his life into a one-line gag. He would be dishonoured and belittled and Orfan wondered if this was an adequate cost for his small fame. He would watch her, all smug and chuckling, pretending to have written all her own comedic material. Ellen would give everyone a stupid gift which shrieking women would pull from under their seats, a book voucher or something, something little, not like Oprah: Oprah gave cars! Everybody knew that. Then Ellen would remind everyone of her homosexuality with unwarranted references to Portia de Rossi. Then they would dance into a commercial break! On stage! Cyclot would hobble, side to side, and the three of them would be up there, dancing together. Ellen would mimic Cyclot's dancing and Orfan would dance like he was stirring a great big pot or rowing a Viking long boat. You know that dance?

'That's not fame, that's exploitation, Cyclot said in the voice of Stephen Hawking, as though reading Orfan's dreams. 'They'll use the agonies of your story, they'll feel pain with you, elation with you, and they'll discard you. You'll be the spiritual and cultural Big Mac. They will gobble you down and your heart will be the wrapper they abandon. Their warmest embrace will become the coldest shoulder. 
They're self-seeking and self-congratulatory and you will be their ammunition. Fame, exploitation, it's all just semantics.'

'You are very wise, Cyclot,' Orfan said, nodding. He considered his robot's sombre words and then wondered what semantics meant. Something bad, he guessed. He wished he lived in a world where he knew what semantics was. Or at least its equivalent in Dhari or Farsi. The truth was, his English was not quite television standard and he knew this was a flaw that must be remedied before he escaped and made the talk show circuit in the United States. Orfan hungered for this in a way that could be equated with the deepest avarice.

For all his dreaming, what Orfan wanted Cyclot to do was take him away to a place with discotheques and thumping bass where he could dance! Where he could straighten his hair, wear fancy pinstripe suits, play snooker and meet girls and be a warlord of the dancefloor. Despite Cyclot's protestations of exploitation, the robot would help him do this. He must! Orfan knew the price of fame was dignity but, like everyone else, he would still struggle against it, trying to find an elusive loophole where fame came on his own terms. Orfan would embrace his fleeting fame in a full-body hug and would not relinquish his vice-like grip until he could freely go to any discotheque in the world. The girls from the discotheque would yell into his ear: 'Hey, you're that guy from TV!'

The Americans would think he was different, his struggles somehow singular. But he was not. He was like all those others who flaunted their fifteen minutes of fame on television. He was no different to them, only some wounds were deeper, and his fame, surely he wanted it more? 